\title{
A Study on Influence of Consumer Usage Knowledge to Purchasing Convenience and Purchase Intention: Taking Sewing Machine as Example
}

\author{
Chun-Hung Lin ${ }^{1}$ \\ An-Jin Shie ${ }^{2}$ \\ Yung-Tsan Jou ${ }^{1}$ \\ Min-I Lai ${ }^{3}$
}

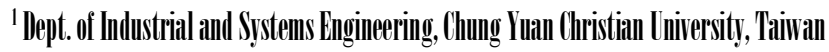

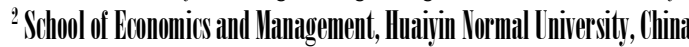

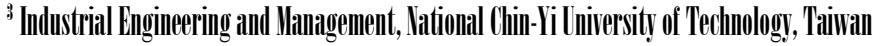

\begin{abstract}
The purpose of this study was to propose a research model by utilizing the consumer usage knowledge and purchasing convenience to explore the relationship among service satisfaction and purchase intention. Consumers of household sewing machine need to obtain professional knowledge for purchasing process, which could facilitate purchase convenience and then increase purchase intention of consumers. Therefore, the consumer usage knowledge was utilized as theoretical basis in this study, and purchasing convenience and consumer attitude was also considered: (i) the consumer usage knowledge whether increases consumer purchasing intention and service satisfaction; (ii) the purchasing convenience whether positively affects consumer service satisfaction and purchasing intention. Structural Equation Model (SEM) was utilized to analyze the structural relationship between measured variables and latent constructs. The study found that (i) consumer usage knowledge of household sewing machine positively affected consumer household sewing machine purchasing convenience, and consumer purchasing intention; (ii) consumer purchasing convenience positively affected purchasing intention for household sewing machine; (iii) consumer attitude after service satisfaction positively affected purchasing convenience. Study revealed that the consumer usage knowledge could increase the consumer's purchasing convenience and purchasing intention; hence, convenient purchasing can improve consumer attitude for satisfaction and purchasing intention.

Keywords: Consumer knowledge, purchase convenience, consumer attitude, purchase intention, household sewing machine

JEL: D83, L64
\end{abstract}

Household sewing machine is a common and affordable device in China and Taiwan. Consumers can easily purchase household sewing machines through many purchasing channels like wholesale, mail order, dealer chain store and second hand market. Meanwhile, the consumer could get information about household sewing machine from various professional websites and blogs related to household sewing machine 
(Chatterley et al., 2006; Ertułrul \& Öztas, 2015) to enhance their knowledge related to sewing machine. This causes consumer to find the reasonable household sewing machine in market easily for best price (Chatterley et al., 2006; Ertułrul \& Öztaș , 2015; Williamson et al., 2005). The consumer than decides purchase based on many factors like function, price and after sale service.

Therefore, the potential questions of this study are: how does consumer usage knowledge influence purchasing convenience, consumer willingness to buy, and consumer attitudes; and how does the consumer purchasing convenience influence consumer willingness to buy and consumer attitudes? These questions are critical for sewing machine industry, but previous literature rarely discussed what factors could influence consumer's purchase intention for sewing machine, and lacked to consider the consumer usage knowledge as a theoretical basis to explore the influence on purchasing convenience, consumer attitude and purchase intention.

To fill the research gap mentioned above, this research proposed a research model by utilizing the consumer usage knowledge and purchasing convenience to explore the relationship among after sale service satisfaction and purchase intention. Therefore, the purpose in this study is to discuss (i) the consumer usage knowledge whether increases consumer purchase intention and after sale service satisfaction; (ii) whether the purchasing convenience affects consumer's after sale service satisfaction and purchase intention positively; and (iii) the real case study technique for household sewing machine is conducted to verify the idea from the proposed research.

The remainder of this paper is organised as follows. The following section presents a review of the literature on consumer knowledge, purchase convenience, consumer attitude and purchase intention. The research method and analysis are then presented to descript how the proposed research model and hypotheses are analysed by Structural Equation Modeling (SEM) and analysis results. The paper concludes with a summary of main findings, implications, and suggestions for future research.

\section{LITERATURE REVIEW}

\section{Consumer Knowledge}




\section{Lin et al.}

According to Piha et al. (2018), consumer knowledge includes subjective knowledge, objective knowledge and familiarity. Donoghue et al. (2016) defines consumer knowledge as storage of information about products in memory or identifying through thoughts, which could make consumer to find out more convenient or easier way in purchasing process, and consumer finds product information through his related memory or experience to purchase the product.

The knowledge is considered as an attribute which reflects that consumer makes decision about purchasing a product could be influenced by product properties and user experience (Kim et al., 2016). The literature explains that consumer attitude has high probability which could be influenced by consumer usage knowledge. Moreover, the consumer knowledge could also increase consumer willingness to purchase and satisfaction. Consumer knowledge shows products familiarity and products professional degree which means users have professional opinions about product. It includes cognitive, attribute knowledge and price knowledge. Cognitive means the level of understanding of consumer about a special product (Pina et al., 2018; Wongkitrungrueng, 2018).

According to above arguments, we speculate, if a business increases the consumer knowledge through a user experience, could result in an influence to purchase convenience, willingness to buy and service satisfaction of consumer, but the previous literature has a research gap in a discussion of antecedents and consequences. To validate this argument, the consumer usage knowledge is utilized as independent variable; and purchases convenience, consumer attitude and consumer willingness to buy, and satisfaction are regarded as dependent variables. Based on the above description, we propose the following three hypotheses:

$\mathrm{H}_{1}$ : The consumer usage knowledge could positively impact the consumer purchase convenience.

$\mathrm{H}_{2}$ : The consumer usage knowledge could positively impact the consumer attitude toward service satisfaction.

$\mathrm{H}_{3}$ : The consumer usage knowledge could positively impact the consumer willingness to buy satisfaction. 


\section{Purchase Convenience}

Shih et al. (2015) mentioned that the purchase convenience could increase purchasing intention and service satisfaction. Because, the author emphasized that purchasing convenience could positively impact consumer attitude for service satisfaction and purchasing intention. Low level of purchasing convenience will decrease consumer attitude and purchase intention (Hasan, 2018; Wu and Chan, 2011). However, the previous literature did not offer a real evidence to illustrate the relationships among consumer purchasing convenience, consumer willingness to buy satisfaction and consumer attitude toward service satisfaction.

To validate this argument, the consumer purchasing convenience is regarded as independent variable; and consumer willingness to buy satisfaction and consumer attitude toward service satisfaction are regarded as dependent variables. Based on the above argument two hypotheses are proposed as follows:

$\mathrm{H}_{4}$ : The consumer purchasing convenient could positively impact the consumer willingness to buy satisfaction.

$\mathrm{H}_{5}$ : The consumer purchasing convenience could positively impact the consumer attitude towards service satisfaction.

\section{Consumer Attitude and Purchase Intention}

Öz et al. (2018) mentioned that the consumer attitude determines desire, and the attitude decides like or disgust things, which could impact consumer purchase intention. Usually people would like to do something they like and try to eliminate things they dislike, the attitude reflects personal beliefs and further determine behavior.

Consumers' attitude about product and some external factors combinedly make consumer purchasing intention. Purchasing intention considered as subjective tendency to choose product for consumer (Zhang et al., 2018). Furthermore, Chi et al. (2009) thought purchasing intention is equivalent to the consumers' willingness to buy products and expected product satisfaction. Arli et al. (2018) mentioned that satisfaction is a feedback which could be good and bad from consumer after using product. Consumer may think positively or negatively about product which could affect satisfaction level as per product using experience and 


\section{Lin et al.}

difficulty of usage. Oliver et al. (1997) cites that if manufacturer of product offers good after sale service that can make consumer satisfied. This research uses Hasan's (2018) definition of purchasing intention and it measures the possibility of purchasing product. For this study, we advocate that consumer willingness to buy satisfaction could be caused by consumer attitude from product experience or expectation to generate the possibility of purchasing household sewing machine. However, the previous literature has a gap in discussion between the consumer attitude and consumer willingness to buy satisfaction for sewing machine.

To validate this argument, the consumer attitude towards service satisfaction is regarded as independent variable; and consumer willingness to buy satisfaction is regarded as dependent variable. Therefore, we propose a hypothesis as follows:

$\mathrm{H}_{6}$ : The consumer attitude toward service satisfaction could increase consumer willingness to buy satisfaction.

\section{METHODOLOGY}

According to research purpose and hypotheses for this research, we used Amos 21 statistical software to conduct analyses. This research studied the consumers having household sewing machine experience in Taiwan. Based on survey design data was collected from consumers who are using household sewing machine. The details of results are mentioned below.

\section{-Descriptive Statistics}

This research used survey design to investigate hypotheses, hence, consumers having household sewing machine experience in Taiwan were contacted during January to March 2016. 200 self-administered surveys were send to consumes and total 163 questionnaires were returned (returned rate $81.5 \%$ ). After checking for errors and 21 questionnaires were found erroneous, therefore, 142 questionnaires were available for final analyses. Chi-square $\chi^{2}$ test for sex and age etc. in formal stage sample group was not at significant level and indicated that sampling is representative of population, stable and homogenous. Population statistic variables for this research includes: sex, age, the experience to use household sewing machine, the type of household sewing machines to use, the purchasing channel to purchase household sewing machine and the 
amount to purchase household sewing machine.

-Reliability and Validity

Reliability and convergent validity was tested through composite reliability (CR) and Average Variance Extracted (AVE). Usually the value of CR equal to or greater than 0.70 is considered good (Hair et al., 1998). Farrell (2010) suggested that the value of AVE for constructs must be greater than 0.50 . The values of CR and AVE can be seen in Table 1 (Appendix-I). The retained items are also shown in table.

Table 2 show the results of model goodness-of-fit. It can be seen that $\chi^{2}$ value meets required level, whereas other fit indexes like goodness-of-fit index (GFI), adjusted goodness-of-fit index (AGFI) and root mean square error of approximation (RMSEA) etc. are also satisfactory. The discriminant validity matrix also showed satisfactory results for discriminant validity for all constructs under study (see Table 3).

\begin{tabular}{cccccc}
\hline Model & $\chi \mathbf{2} / \mathbf{d f}$ & GFI & AGFI & CFI & RMSEA \\
\hline $\begin{array}{c}\text { Household sewing machine in } \\
\text { consumer usage knowledge }\end{array}$ & 1.417 & 0.973 & 0.977 & 0.925 & 0.037 \\
\hline $\begin{array}{c}\text { Consumer purchasing } \\
\text { convenience }\end{array}$ & 2.097 & 0.995 & 0.981 & 0.962 & 0.075 \\
\hline $\begin{array}{c}\text { Consumer attitude for after } \\
\text { service satisfaction }\end{array}$ & 1.106 & 0.986 & 0.979 & 0.974 & 0.064 \\
\hline Consumer purchasing intention & 1.543 & 0.988 & 0.963 & 0.993 & 0.072 \\
\hline $\begin{array}{c}\text { Recommended value } \\
\text { Analysis result }\end{array}$ & $\begin{array}{c}>0.9 \\
\text { Consistent }\end{array}$ & $\begin{array}{c}>0.9 \\
\text { Consistent }\end{array}$ & $\begin{array}{c}\text { Consistent } \\
\text { Consistent }\end{array}$ & $\begin{array}{c}<0.08 \\
\text { Consistent }\end{array}$ \\
\hline
\end{tabular}

Table 2. Test of Goodness-of-Fit

\section{Hypotheses Testing}

In order to know causal relationships for household sewing machine in consumer usage knowledge for consumer purchasing convenience satisfaction, consumer attitude for after service satisfaction and consumer purchasing intention satisfaction. The linear structural analysis is utilized to verify for this research. Based on the above described all indexes, the fitness condition is good for overall model. Therefore, the relation model is accepted model in this research. The relation model includes three variables: A variable means consumer usage knowledge; $\mathrm{B}$ variable means purchasing convenience; $\mathrm{C}$ variable means after sale 


\section{Lin et al.}

service attitude satisfaction; $D$ variable is purchasing intention.

\begin{tabular}{ccccc}
\hline Facet & $\begin{array}{c}\text { Household sewing } \\
\text { machine in } \\
\text { consumer usage } \\
\text { knowledge }\end{array}$ & $\begin{array}{c}\text { Household sewing } \\
\text { machine } \\
\text { purchasing } \\
\text { convenience }\end{array}$ & $\begin{array}{c}\text { Household } \\
\text { sewing machine } \\
\text { after service } \\
\text { attitude }\end{array}$ & $\begin{array}{c}\text { Household sewing } \\
\text { machine } \\
\text { purchasing } \\
\text { intention }\end{array}$ \\
\hline $\begin{array}{c}\text { Household sewing machine in } \\
\text { consumer usage knowledge }\end{array}$ & $\mathbf{0 . 7 9}$ & & & \\
\hline $\begin{array}{c}\text { Consumer purchasing } \\
\text { convenience }\end{array}$ & 0.53 & $\mathbf{0 . 8 6}$ & & \\
\hline $\begin{array}{c}\text { Consumer attitude after service } \\
\text { satisfaction }\end{array}$ & 0.47 & 0.57 & $\mathbf{0 . 8 4}$ & \\
\hline Consumer purchasing intention & 0.73 & 0.66 & 0.49 & $\mathbf{0 . 9 6}$ \\
\hline
\end{tabular}

Table 3. Discriminant Validity Matrix

As shown in Table 4 the household sewing machine consumer usage knowledge has a significant positive impact on household sewing machine purchasing convenience $(\beta=0.72)$, therefore, hypothesis 1 stood valid. The impact of consumer usage knowledge on after sale service satisfaction was not significant, therefore, hypothesis 2 was not proved. The relationship between consumer usage knowledge and and purchasing intention was significant $(\beta=0.52)$, hence, hypothesis 3 was proved. Consumer purchasing convenience positively and significantly impacted after sale service satisfaction $(\beta=0.67)$, therefore, hypothesis 4 was validated. Consumer purchase convenience impacted purchase intention significantly $(\beta=$ 0.38), therefore, hypothesis 5 was proved. Lastly, after sale service satisfaction did not impact purchase convenience, hence, hypothesis 6 was not validated.

Table 5 reflects that for total effect, consumer usage knowledge has indirect effect for purchasing intention and total effect is 0.8481 . Purchasing convenience satisfaction has indirect purchasing intention and total effect is 0.4403 . Consumer usage knowledge will influence directly for household sewing machine purchasing convenience satisfaction, total effect is 0.60 . Whereas, consumer attitude will influence purchasing intention directly and total effect is 0.09 .

\section{CONCLUSION}

This research discussed and linked four important facets of household sewing machine i.e. use satisfaction, 


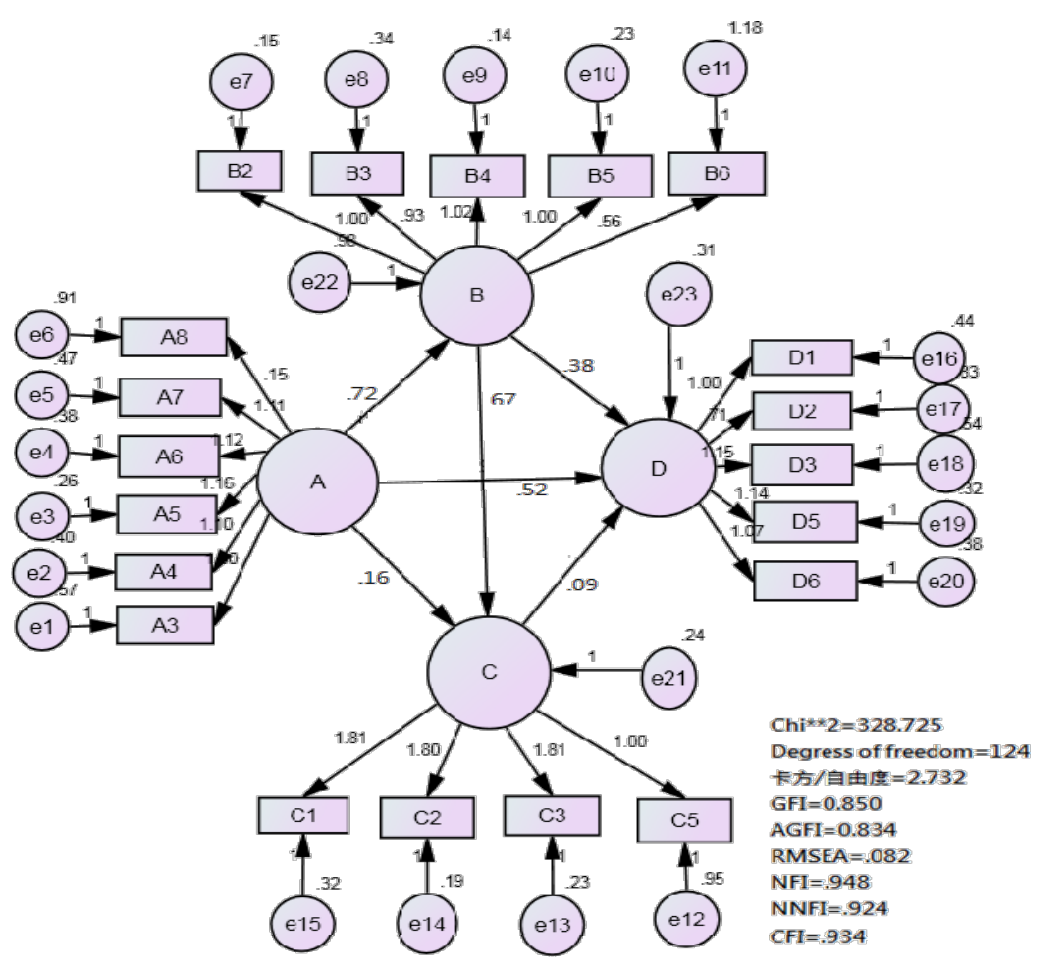

Figure 4. Path Analysis

\begin{tabular}{|c|c|c|c|c|c|}
\hline Hypothesis & Latent variables & $\begin{array}{c}\text { Latent dependent } \\
\text { variables }\end{array}$ & $\begin{array}{c}\text { Path } \\
\text { Analysis }\end{array}$ & t value & Result \\
\hline Hypothesis 1 & $\begin{array}{c}\text { Household sewing } \\
\text { machine consumer } \\
\text { usage knowledge }\end{array}$ & $\begin{array}{c}\text { Consumer purchasing } \\
\text { convenience }\end{array}$ & 0.72 & $6.589 * * *$ & Valid \\
\hline Hypothesis 2 & $\begin{array}{c}\text { Household sewing } \\
\text { machine consumer } \\
\text { usage knowledge }\end{array}$ & $\begin{array}{c}\text { Consumer attitude } \\
\text { after service } \\
\text { satisfaction }\end{array}$ & 0.16 & 1.236 & Not valid \\
\hline Hypothesis 3 & $\begin{array}{l}\text { Household sewing } \\
\text { machine in consumer } \\
\text { usage knowledge }\end{array}$ & $\begin{array}{l}\text { Consumer purchasing } \\
\text { intention }\end{array}$ & 0.52 & $5.448 * * *$ & Valid \\
\hline Hypothesis 4 & $\begin{array}{c}\text { Consumer purchasing } \\
\text { convenience } \\
\text { satisfaction } \\
\end{array}$ & $\begin{array}{c}\text { Consumer attitude } \\
\text { after service } \\
\text { satisfaction } \\
\end{array}$ & 0.67 & $5.241 * * *$ & Valid \\
\hline Hypothesis 5 & $\begin{array}{c}\text { Consumer purchasing } \\
\text { convenience } \\
\text { satisfaction }\end{array}$ & $\begin{array}{l}\text { Consumer purchasing } \\
\text { intention }\end{array}$ & 0.38 & $3.852 * * *$ & Valid \\
\hline Hypothesis 6 & $\begin{array}{l}\text { Consumer attitude after } \\
\text { service satisfaction }\end{array}$ & $\begin{array}{c}\text { Consumer purchasing } \\
\text { convenience }\end{array}$ & 0.09 & 1.326 & Not valid \\
\hline
\end{tabular}

Table 4. Path Correlation Coefficient in Study Model 


\begin{tabular}{|c|c|c|c|c|c|c|c|}
\hline \multirow[t]{2}{*}{ Latent variables } & \multicolumn{2}{|c|}{$\begin{array}{c}\text { Consumer purchasing } \\
\text { convenience } \\
\text { satisfaction } \\
\text { (B variable) }\end{array}$} & \multicolumn{2}{|c|}{$\begin{array}{l}\text { Consumer attitude after } \\
\text { service satisfaction } \\
\text { (C variable) }\end{array}$} & \multicolumn{3}{|c|}{$\begin{array}{c}\text { Consumer purchasing intention } \\
\text { satisfaction } \\
\text { (D variable) }\end{array}$} \\
\hline & Direct & Indirect & Direct & Indirect & Direct & Indirect & $\begin{array}{l}\text { Total } \\
\text { effect }\end{array}$ \\
\hline $\begin{array}{l}\text { Household sewing } \\
\text { machine in consumer } \\
\text { usage knowledge (A } \\
\text { variable) }\end{array}$ & 0.72 & - & 0.16 & - & 0.52 & 0.3281 & 0.8481 \\
\hline $\begin{array}{l}\text { Consumer purchasing } \\
\text { convenience } \\
\text { satisfaction (B variable) }\end{array}$ & \multicolumn{2}{|c|}{ No path } & 0.67 & - & 0.38 & 0.0603 & 0.4403 \\
\hline $\begin{array}{l}\text { Consumer attitude after } \\
\text { service satisfaction }(\mathrm{C} \\
\text { variable })\end{array}$ & \multicolumn{2}{|c|}{ No path } & \multicolumn{2}{|c|}{ No path } & 0.09 & - & 0.09 \\
\hline Explanatory power & \multicolumn{2}{|c|}{0.417} & \multicolumn{2}{|c|}{0.546} & \multicolumn{3}{|c|}{0.51} \\
\hline
\end{tabular}

Table 5. Influence Effect for Each Variable

purchasing convenience, consumer attitude with after sales service and purchasing intention, analyzing these facets whether they can directly influence consumer purchasing behavior. Study used measurement model and structural model analyses to test hypotheses. Overall results can be seen in Table 4 and 5 . It is observed that household sewing machine consumer usage knowledge to consumer with household sewing machine purchasing intention has indirect effect and total effect is 0.8481 . Consumer with household sewing machine purchasing convenience to consumer with household sewing machine purchasing intention has indirect effect and total effect is 0.4403 . Household sewing machine in consumer usage knowledge to consumer with household sewing machine purchasing convenience has direct effect and total effect is 0.72 . Consumer attitude with after service satisfaction to consumer with household sewing machine purchasing intention has direct relation and total effect is 0.09 .

\section{IMPLICATIONS}

This study filled up the research gap which is the importance of consumer usage knowledge in sewing machine industries. According to the proposed research finding, the consumer usage knowledge about sewing machine can increase consumer's purchasing convenience and purchasing intention. Therefore, this study has verified that increasing consumer usage knowledge can facilitate more convenient and easier purchasing behavior. Moreover, the more convenient purchasing can improve consumer attitude and 
satisfaction and increase purchasing intention. In contrast, the previous literature merely focused on the discussion of the important factors (e.g. products quality, function of price) influenced consumer's purchase intention for sewing machine.

According to the research findings, we find that consumer usage knowledge impacts the consumer purchases convenience positively, and also impacts to consumer purchasing intention positively. Thus, it implies that business should offer more product information to increase consumer usage knowledge, for example, user experience sharing on social network platforms such as: Facebook and community websites about sewing machine. Meanwhile, the new kind of sales channel must offer many kind of service like DIY package and kits, household sewing machine educational books, rental and repair services etc. to develop new business in market. The solution will also increase consumer's product cognition, concept and attitude, and also facilitate improving purchasing convenience and after sale satisfaction during purchasing process. It was found that the consumer usage knowledge increase also stimulate consumer purchasing intention. Next, the consumer purchasing convenience satisfaction impacts consumer attitude and purchasing intention positively. Thus, it implies that the improvement of consumer usage knowledge will improve purchasing convenience, e.g. offering product trial on sales point or demo videos, which not only deepen consumer cognition and improve attitude about the product.

\section{LIMITATIONS AND FUTURE DIRECTIONS}

This study has some limitations that need careful consideration. First, the respondents in this study were referred from dealership, however, having sewing machine experience. The selection of a single sample source may raise concerns regarding the issue of generalisability. Thus, the findings of this study may not be generalised to other consumers (e.g. online shops and general electric appliances stores) and salespersons. The results of this study should be validated in different sample source settings, various consumers or salesperson.

Second, the cross-sectional design of the study did not allow us to test long-term causal relationships among the variables. Future research tracking changes in variables over time would strengthen the ability to 


\section{Lin et al.}

make causal inferences. Moreover, although the directions of the relationships investigated in our study were

proposed based on the theoretical basis, opposite directions may be plausible as well. This possibility, however, does not negate the contribution of this study to the literature. More investigation in future studies would verify the causal relationships among the variables. Longitudinal study design is needed to examine the proposed processes.

\section{REFERENCES}

Arli, D., Tan, L. P., Tjiptono, F., \& Yang, L. (2018). Exploring consumers' purchase intention towards green products in an emerging market: The role of consumers' perceived readiness. International Journal of Consumer Studies, 42(4): 389-401.

Chatterley, J. J., Blotter, J. D., Sommerfeldt, S. D., \& Leishman, T. W. (2006). Sound quality assessment of sewing machines. Noise Control Engineering Journal, 54(3): 212-220.

Chi, H. K., Yeh, H. R., \& Yang, Y. T. (2009). The impact of brand awareness on consumer purchase intention: The mediating effect of perceived quality and brand loyalty. The Journal of International Management Studies, 4(1): 135-144.

Donoghue, S., van Oordt, C., \& Strydom, N. (2016). Consumers' subjective and objective consumerism knowledge and subsequent complaint behaviour concerning consumer electronics: a South African perspective. International Journal of Consumer Studies, 40(4): 385-399.

Erturrul, I., \& Öztaş, T. (2015). The application of sewing machine selection with the multi-objective optimization on the basis of ratio analysis method (MOORA) in apparel sector. Tekstil ve Konfeksiyon, 25(1): 80-85.

Farrell, A. M. (2010). Insufficient discriminant validity: A comment on Bove, Pervan, Beatty, and Shiu (2009). Journal of Business Research, 63(3): 324-327.

Hair, J. F., Black, W. C., Babin, B. J., Anderson, R. E., \& Tatham, R. L. (1998). Multivariate data analysis (Vol. 5). New Jersey: Prentice hall Upper Saddle River.

Hasan, A. (2018). Impact of Store and Product Attributes on Purchase Intentions: An Analytical Study of Apparel Shoppers in Indian Organized Retail Stores. Vision, 22(1): 32-49.

Kim, Y., Yun, S., Lee, J., \& Ko, E. (2016). How consumer knowledge shapes green consumption: An empirical study on voluntary carbon offsetting. International Journal of Advertising, 35(1): 23-41.

Oliver, R. L., Rust, R. T., \& Varki, S. (1997). Customer delight: foundations, findings, and managerial insight. Journal of retailing, 73(3): 311-336.

Öz, B., Unsal, F., \& Movassaghi, H. (2018). Consumer attitudes toward genetically modified food in the United States: Are Millennials different? Journal of Transnational Management, 23(1): 3-21.

Piha, S., Pohjanheimo, T., Lähteenmäki-Uutela, A., Křečková, Z., \& Otterbring, T. (2018). The effects of consumer knowledge on the willingness to buy insect food: An exploratory cross-regional study in Northern and Central Europe. Food Quality and Preference, 70: 1-10.

Shih, S. P., Yu, S., \& Tseng, H. C. (2015). The study of consumers' buying behavior and consumer satisfaction in beverages industry in Tainan. Journal of Economics, Business and Management, 3(3): 391-394.

Williamson, N. C., Kissling, G., Cassill, N., \& Odinokov, D. (2005). Import market potential, import market competitiveness and add/drop foreign market decisions of U. S. exporters of sewing machines. Competitiveness Review, 15(1): 57-71.

Wongkitrungrueng, A. (2018). Exploring how and why consumers create unintended uses of products. International Journal of Business Innovation and Research, 16(4): 453-470.

Wu, S. I., \& Chan, H. J. (2011). Perceived service quality and self-concept influences on consumer attitude and purchase process: A comparison between physical and internet channels. Total Quality Management, 22(1): 43-62.

Zhang, Y., Jing, L., Bai, Q., Shao, W., Feng, Y., Yin, S., \& Zhang, M. (2018). Application of an integrated framework to examine Chinese consumers' purchase intention toward genetically modified food. Food Quality and Preference, 65: 118-128. 
Appendix-I

\begin{tabular}{|c|c|c|c|c|c|c|c|}
\hline Facet & Study variables & $\begin{array}{l}\text { Factor } \\
\text { loading }\end{array}$ & $\mathbf{R 2}$ & $t$-value & $\begin{array}{l}\text { Standard } \\
\text { deviation }\end{array}$ & CR & AVE \\
\hline \multirow{5}{*}{$\begin{array}{l}\text { Household sewing } \\
\text { machine in consumer } \\
\text { usage knowledge }\end{array}$} & Product 2 & 0.824 & 0.478 & 9.988 & 0.059 & \multirow{5}{*}{0.9584} & \multirow{5}{*}{0.856} \\
\hline & Product 5 & 0.877 & 0.295 & 8.856 & 0.045 & & \\
\hline & Product 6 & 0.852 & 0.365 & 7.365 & 0.035 & & \\
\hline & Product 7 & 0.832 & 0.556 & 8.954 & 0.043 & & \\
\hline & Product 8 & 0.884 & 0.324 & 9.245 & 0.053 & & \\
\hline \multirow{4}{*}{$\begin{array}{c}\text { Consumer purchasing } \\
\text { convenience } \\
\text { satisfaction }\end{array}$} & Convenience 2 & 0.523 & 0.752 & 10.756 & 0.067 & \multirow{4}{*}{0.9135} & \multirow{4}{*}{0.7023} \\
\hline & Convenience 4 & 0.847 & 0.236 & 5.624 & 0.025 & & \\
\hline & Convenience 5 & 0.832 & 0.452 & 8.456 & 0.038 & & \\
\hline & Convenience 6 & 0.965 & 0.178 & 5.236 & 0.027 & & \\
\hline \multirow{5}{*}{$\begin{array}{l}\text { Consumer attitude for } \\
\text { after service } \\
\text { satisfaction }\end{array}$} & Service 1 & 0.756 & 0.963 & 10.841 & 0.087 & \multirow{5}{*}{0.9074} & \multirow{5}{*}{0.6651} \\
\hline & Service 2 & 0.963 & 0.356 & 8.637 & 0.038 & & \\
\hline & Service 3 & 0.923 & 0.186 & 6.785 & 0.030 & & \\
\hline & Service 4 & 0.913 & 0.245 & 6.824 & 0.032 & & \\
\hline & Service 6 & 0.642 & 0.985 & 10.884 & 0.089 & & \\
\hline \multirow{4}{*}{$\begin{array}{l}\text { Consumer purchasing } \\
\text { intention satisfaction }\end{array}$} & intention 2 & 0.788 & 0.754 & 10.423 & 0.069 & \multirow{4}{*}{0.9289} & \multirow{4}{*}{0.7841} \\
\hline & intention 4 & 0.896 & 0.265 & 8.098 & 0.026 & & \\
\hline & intention 6 & 0.942 & 0.085 & 3.754 & 0.020 & & \\
\hline & intention 8 & 0.857 & 0.299 & 9.023 & 0.032 & & \\
\hline
\end{tabular}

Table 1. Loadings and Reliability Analysis for Each Variable in Research Model 